\title{
Husserl on Collective Intentionality
}

Szanto, Thomas

Published in:

The Phenomenological Approach to Social Reality

DOI:

10.1007/978-3-319-27692-2_7

Publication date:

2016

Document version

Peer reviewed version

Citation for published version (APA):

Szanto, T. (2016). Husserl on Collective Intentionality. In A. Salice, \& H. B. Schmid (Eds.), The

Phenomenological Approach to Social Reality : History, Concepts, Problems (pp. 145-172). Springer. Studies in the Philosophy of Sociality Vol. 6 https://doi.org/10.1007/978-3-319-27692-2_7 


\title{
Husserl on Collective Intentionality
}

\author{
Thomas Szanto \\ (Center for Subjectivity Research, University of Copenhagen)
}

\section{Introduction}

Literature on Husserl's theory of empathy and intersubjectivity abounds, especially with regard to how such notions relate to his 'transcendental solipsism.' What is little known, however, is that Husserl, in his later work, offers a highly original theory of collective intentionality, an issue that is at the forefront of contemporary analytic philosophy of action. In this paper, I shall address this hitherto neglected aspect of Husserlian phenomenology and argue that Husserl's contribution, on closer scrutiny, not only stands on an equal footing with contemporary accounts but, indeed, also helps to alleviate some of their shortcomings.

To be sure, Husserl's intriguing "social ontology" (Hua XIII, 102) has not gone wholly unnoticed. ${ }^{1}$ Yet, those few examples of existing literature typically have a different focus than my own, concentrating, instead, on specific constitutional issues or ontological (sub-)domains of social reality, intricate issues that I shall not pursue in great detail here. ${ }^{2}$ Additionally, with even fewer notable exceptions ${ }^{3}$, there is hardly any work that systematically examines Husserl's possible contribution to the current debate on collective intentionality. Moreover, both Husserl's preeminent early phenomenological successors and contemporary scholars either do not seriously consider his theory of 'higher order persons' and 'common minds' (Gemeinge$i s t)$ and their cognate conceptions altogether, or else the verdict is outright dismissive. ${ }^{4}$ Eventually, some contemporary critics regard them simply as relics from a past that notoriously led many of Husserl's contemporaries to give way to the collectivistic aberrations of the social and political thought in the first quarter of the twentieth century. Conversely, and somewhat ironically, critics have recently claimed that Husserl's common mind, far from being truly anti-individualist, is rather "brainwashed" by Cartesian individualism (Schmid 2000, 2005).

\footnotetext{
${ }^{1}$ Evidence suggests that it was, indeed, Husserl who first coined the very term 'social ontology' (soziale Ontologie) — a now well-established research field within current analytic philosophy-in a text from 1910, cf. Salice 2013. I appreciate help from Thomas Vongehr at the Husserl Archives, KU Leuven, for having verified this in the original typescript.

2 See the respective work on Husserl's account of 'higher order persons' and 'communal minds' (Toulemont 1962; Allen 1978), on specific socio-ontological sub-domains and their foundational structure, such as Husserl's distinction between various types of social collectives (Toulemont 1962, and Perreau 2013), or specific types of 'socialities of subordination' and of 'equitability' and Husserl's theory of the state (Schuhmann 1988), positive and/or critical comparisons between Husserl's and Searle's social ontology (Thomasson 1997; Johansson 2003). Theunissen's (1965/1977) and Strasser's (1975) contributions, though they first used the term 'social ontology' (Sozialontologie) in the (German) literature after Husserl, do not deal with Husserl's social ontology proper but, rather, with his account of intersubjectivity and intersubjective monadology; for an early critical and, indeed, not very optimistic, account of Husserl's possible contribution to the philosophy of the social sciences more generally, see Neisser 1959; cf. also Uygur 1959, Schmid 2000 and Mulligan 2001, and most recently Miettinen 2014 .

3 See Mathiesen 2005; Caminada 2011; Salice 2013, and most detailed Chelstrom 2013.

${ }^{4}$ See esp. the critiques of higher order collectivities in Schütz 1957, 114f., or Kaufmann 1930 and 1944, $163 f$.
} 
In marked contrast to such critical approaches, I wish to show that Husserl in fact offers a rich phenomenological social ontology of various types of collectives. Moreover, I shall argue that Husserl provides all conceptual prerequisites for a genuinely novel phenomenological account of collective intentionality. Notice that the emphasis here is on prerequisites: though I contend that we find all of the building blocks, however scattered, in the work of Husserl, in this paper, I endorse a systematic and reconstructive approach rather than a purely exegetical one.

To make my case, my argument proceeds as follows: I start by mapping the terrain with an outline of the multi-layered structure of the constitutional process, which Husserl labels the 'socialization' or 'communalization' (Vergemeinschaftung) of individuals. In particular, I shall consider the differences in the intentional integration of individuals and collectives in terms of intersubjective, social, communal and collective intentionality, respectively (Sec. 1). Against a brief survey of the most influential current accounts of collective intentionality (Sec. 2), I then concentrate on Husserl's alternative construal and demonstrate how it entails a robust anti-individualism regarding both the form and the subject of we-intentions (Sec. 3). Finally, I address two central objections and vindicate the Husserlian account; here I argue that, contrary to appearances, Husserl does not fall prey to committing a content/vehicle type of fallacy by inferring from the jointness of the contents, or the we-modal feature of collective intentionality, that there is one joint vehicle (one intention) or, worse, some collectively conscious, 'bearer-entity' of such (Sec. 4). I conclude by recapitulating the core merits of the Husserlian account of collective intentionality over its dominant, contemporary models.

\section{Intersubjective, Social, Communal, and Collective Intentionality: An Outline of Husserl's Intentional Sociology}

Husserl's account of collectives and social entities enters stage at a relatively late phase of the foundational process of social reality and, here, in turn, does so as one of the so-called "regional ontologies" (Hua III/1, 19f.). ${ }^{5}$ This regional ontology, "the systematic ontology of social entities and facts" (systematische Ontologie sozialer Gegebenheiten), or "social ontology" for short, can be seen as the phenomenological equivalent of sociology, and it is in this sense that Husserl employs the concepts "descriptive sociology" (Hua XIII, 102f.) or "intentional sociology” (Hua XXXIX, 389). The "social atoms" (Gilbert 2003) of Husserl's intentional sociology are individuals and their intentional interrelations, i.e., the directedness of intentional acts upon one-another. ${ }^{6}$ It is crucial to bear in mind, however, that the 'socialization' of individuals, on the one hand, and the constitution of social communities, on the other, for Husserl, are correlative, or interdependent constitutional processes. It is not as if there were pre-social atoms engaging in social acts and, eventually, constituting social communities. Rather, the socialization of individuals - their being constituted as full-fledged social beings who enter-

\footnotetext{
5 Presumably, even though this is not fully clear in Husserl, the region to which social reality belongs to, as a material 'sub-region', is the region of cultural, or spiritual (geistig), intentional achievements, cf., e.g., Hua IV, 347,379 .

${ }^{6}$ See Hua XIII, 103: "In the social sphere, the basic units of calculation (Grundeinheiten der Rechnung) are individual human beings and their act-relations upon one-another (Aktberiehungen aufeinander)," a dictum that, on the face of it, resonates with Schütz' (1932) and Weber's (1922) methodological solipsism.
} 
tain complex social relations-on the one hand, and their communalization-their constituting social groups and communities - are, as it were, just two constitutional sides of one and the same intersubjective process. ${ }^{7}$ Hence, the phenomenological basis of collectivity and community is already at play at the level of those intersubjective processes that imbue the most basic sensory - that is to say, affective, or emotional—life of individuals, including their drives, or sensory perceptions (Hua VI, 166; XIV, 196ff.; cf. Strasser 1975). This is essentially what Husserl means when he claims that an ego "is what it is" only as somebody who bears an Other and, indeed, all others, in her very being and that it is "nonsense" that any subject, even any "absolute being," could exist as a solus ipse (Hua XV, 336, 371).

What, then, are social entities and, in particular, collectives, and how are they constituted? Most generally viewed, social entities, for Husserl, are "objectivities of higher-order" (Objektitäten höherer Stufe; Hua XIII, 101, Fn.; cf. ibid., 99, Fn. 3). Notice that by using the singulare tantum concept 'objectivity' in the plural, Husserl marks the non-ordinary status of such 'entities': they are neither mere intentional objects nor simply subjects, that is, not subjects at the same, constitutionally-foundational level as individual subjects. This, as shall become clear in the following (sec. 3-4), is not to say that, for Husserl, collectives were merely objectivities. Rather, in specific cases, collectives can well be proper 'subjectivities', even if Husserl uses the concept 'subjectivity,' when attributed to specific sorts of groupings of subjects, in the distinctive sense of being of a higher order. ${ }^{8}$ Consider also that being a higher order entity, be it an objectivity or subjectivity, is far from being exclusively reserved to social entities. Husserl equally characterizes the "concrete objective" (individual) "human person" as a "unity of higher order" (Hua XIV, 425). Furthermore, from the very start of introducing this concept, Husserl makes it very clear that social objectivities are not mere arbitrary "collections" or aggregates of individuals but "social unities" in their own right (Hua IV, 196; VIII, 198; XIII, 99-104; XXVII, 22, 27).

Higher order social objectivities are constituted by four interrelated and gradually evolving constitutional processes that jointly make up what Husserl calls the "intentional implication" (intentionale Implikation) of one ego in another, or, significantly, the "intentional intertwinement of communalization" (Ineinander der Vergemeinschaftung) (Hua VI, 258f.).?

\footnotetext{
7 Similarly, at a higher level of socialization, Husserl points to the "parallel constitution" of communal (higher order) subjects and their communal engagements and accomplishments (Hua XIV, 193).

${ }^{8}$ Pace Chelstrom 2013, who claims (without, however, consulting either Hua XIII, XIV, XV or other later texts of Husserl) that Husserl "in no way extends a sense of subjectivity to intersubjective groupings of subjects (...) and does not speak of them as subjectivities whatsoever" (Chelstrom 2013, 52), a claim that, as a number of quotes below will show, is, at least from point of view of the textual evidences, plainly wrong; cf. Szanto $2014 \mathrm{~b}$. 9 See also Hua VI, 252, 259, 417; XV, 371, 377, and Hua Mat VIII, 20, 278. Husserl uses a series of other concepts to refer to this intentional implication, such as "interweaving of intentionality" (ineinandergeflochten; Hua VIII, 128), or the "intertwinement of constitution" (Ineinander der Konstitution), "the amazing fashion [in which one's] intentionality reaches into that of the other and vice versa" (Hua VI, 257f.). Note that the individuals who intentionally integrate thusly remain, in fact (reell), 'separated'. This is the gist of Husserl's demarcation of "intentional intertwinement" (intentionales Ineinander) and "real separateness" (reelles Auseinander) (Hua XV, 371, 377). Consider, however, that there is a level of analysis and a respective transcendental level of constitution wherein intentional interpenetration precedes their separateness such that Husserl, indeed, speaks of the intentional intertwinement as a "metaphysical arch-fact" (metaphysische Urtatsache; Hua XV, 366). Here is a revealing passage from the Crisis: "(...) within the vitally flowing intentionality (lebendig strömende Intentionalität) in which the life of an ego-subject consists, every other ego is already intentionally implied from the very start by way of empathy and the empathy-horizon (Einfühlungshorizont). Within the universal epoché (...), it becomes evident that there is no separation of mutual externality at all for souls in their own essential nature. What is a mutual separateness (Außeinander) for the natural-mundane attitude of world-life prior to the epoché, because of the
} 
Accordingly, and quite unlike the often all-too homogenous account of collective intentionality (henceforth: CI) in contemporary social ontology, in Husserl, we may devise four distinct social types of intentionality: call them intersubjective, social or socio-communicative, communal and collective intentionality respectively. ${ }^{10}$ To be sure, Husserl has no clear taxonomy, let alone any precise criteria of individuation of these four types; I suggest, however, that there is enough textual and, above all, systematic evidence in his work that Husserl does, in fact, properly distinguish between them. The differences between these social forms of intentionality are due to differences regarding the underlying constitutional processes of socialization/communalization, the robustness of intentional integration and the subject, and the content and the object of the respective intentional engagements. More precisely, the constitutional moments of the complex foundational process of socialization and communalization of individuals are as follows: 1.) (individual and collective) empathy; 2.) the constitution of a "transcendental We" and the correlative social lifeworld and objectivity 3.) explicit socio-communicative acts and joint attention; 3.); and, finally, 4.) various forms of CI proper. In order to get a firm grip on Husserl's account of CI, it is the fine-grained structure of this multi-dimensional constitutional process of communalization to which we must now turn our attention.

(1) On the most basic level of the constitution of persons qua atoms of social life, we have empathy (Einfühlung). Empathy, for Husserl, roughly, is an irreducible intentional experience of another subject (Fremderfahrung), one that consists in encountering another animate body, its recognition as another 'lived body' (Leib), and, eventually, its recognition as another subject or ego (alter ego) with its own conscious intentional life. This process of recognition takes its cue from the bodily manifestations and verbal expression (gestures, mimics, explicit communication, etc.) of the Other and, essentially, happens by means of the so-called "analogical appresentation," analogous to the "re-presentation" (Vergegenwärtigung) of one's own past experiences, and "associative coupling" or "pairing" (Paarung) of the respective experiences (Hua I, 138ff.). What is crucial to note for present purposes is that empathy typically amounts to dyadic, I-Thou relations (Ich-Du-Beriehungen). Accordingly, intersubjective, empathy-based intentionality entails Other-directed intentional acts, whose subject is an individual and whose object, the target of empathy, includes one or more other subjects and their respective intentional properties. ${ }^{11}$

(2) The second central moment in the constitution of communal life is the constitution of the universally shared lifeworld and its subjective correlate, the "transcendental We" (Hua I, 137). I propose to subsume this highly complex constitutional process under the heading of

\footnotetext{
localization of souls in living bodies, is transformed in the epoché into a pure, intentional interweaving (wechselseitiges intentionales Ineinander)." (Hua VI, 259); see also the quote from Hua XV, 335 below (sec. 4).

${ }^{10}$ Here, I am indebted to De Vecchi 2011 and 2014, who similarly distinguishes "intersubjective," "social," and "collective intentionality," as well as further types, some of which are also to be found in Husserl's phenomenology of sociality, including, e.g., affective (as distinct from cognitive or practical), intersubjective and collective intentionality (cf., e.g., Hua XIV, 196ff. and Husserl 1923); see also Schmid 2009.

11 This is not to say that empathy for Husserl (or for Stein 1917) must necessarily target single individuals only, or that there cannot indeed be such as collective empathy, whose target is not an individual but a collective of individuals or a community. Notice that, in such social or collective forms of empathy, however, the empathizer aims at understanding, not so much the alleged experiences of collectives or communities, as in the individual case, but, rather, the collective's "social functions," values, etc. (cf. Hua IV, 200; VIII, 137; XIII, 99). For more on the possibility of such collective forms of empathy, esp. in Stein, cf. Szanto forthcoming b.
} 
'communal intentionality'. ${ }^{12}$ What happens here, roughly, is, above and beyond empathy's IThou-synthesis/pairing and social act's I-Thou-relations (see below), a specific "Wesynthesis" (Wir-Synthesis), thereby constituting a "general We" (allgemeines Wir). The objective intentional correlate of this We is "the intersubjectively identical lifeworld-for-all" (Hua VI, 175f., cf. 163ff.). The important point here is that there is an "interpersonal intentionality" that, by way of a "synthesis of individuals," not only establishes a "social plurap' (soziales Plural), but, at the same time, a founded and yet "intrinsic unity" (innere gestiftete Einheit) (Hua VIII, 198). This internally-synthesized social plural, being a transcendental (inter-)subjectivity, has (just as their members have) the individual egos, a proper "intersubjective sphere of ownness" (Hua I, 137). Moreover, this transcendental We has its own constitutive function, specifically, the constitution of an objective world, and, ultimately, of objectivity. As such, i.e. as 'constitutive intersubjectivity' (Zahavi 2001, 115), it is a kind of transcendental primitive in the ontology of social reality. Now, the subjects of such communal intentionality are still individuals. However, as members of the transcendental We, as inhabitants of the social lifeworld, their intentional experiences are such that they are impregnated, as it were, by a 'wemode'. At bottom, this means the sharing of a first-person plural perspective onto the common lifeworld, and it is precisely in this sense that Husserl speaks of a "nos cogitamus" (Hua VIII, 316). ${ }^{13}$ Husserl spells out this transcendental commonality of experiencing in terms of the 'typicality' and 'habituality' of apperceiving the common lifeworld. The commonality includes both types of intentional content, as well as types of experiential modes, or the form of experiences. For example, all of us have certain X-type-perceptions and share certain beliefs based on such X-type-perception (cf. Chelstrom 2013, 171).

(3a) Next, we have explicit and reciprocal socio-communicative acts (kommunikative soziale Akte; Akte der sozialen Wechselberiehung; Hua I, 159; IV, 194; XIII, 98ff.; XIV, 166ff.), which Husserl also labels "social I-Thou-acts and We-acts" (soziale Ich-Du-Akte und Wir-Akte; VIII, 137; cf. XV, 19). Here, one is explicitly addressing others via notifications, acknowledgments (Kenntnisnahme), reports (Mitteilung), etc., and takes specific normative stances towards them. Paradigmatic examples of such "social acts" are promises, encouragements, requests, orders, indications, suggestions, or agreements. Similarly with empathy, the subjects of social acts are individuals, and they also have an Other-directed character in that they are directly addressed to one or more other subjects, or even a collection of individuals (e.g., I may order a group to do something). Not only are they similar in this respect, but social acts also have their phenomenological basis in empathy. However, it is important not to confuse the two social stances (cf. Hua XIII, 98ff.). One significant difference between social acts and empathy concerns reciprocity. Empathy, though it can well be reciprocal and even assume collective forms, is not necessarily reciprocal. This is quite unlike socio-communicative acts, which Husserl frequently characterizes as reciprocal or mutual social relations (soziale Akte der Wechselberiebung). Touching on this, it is noteworthy that Husserl occasionally distinguishes "recip-

\footnotetext{
${ }^{12}$ Cf. Hua XIV, 74, 94, 99, 173, 196ff.; XV, 331ff.; XXXIX, 260ff., 385ff., 491; Mat VIII, 178ff., $369 \mathrm{ff.,} 430 \mathrm{ff}$. 13 Carr puts this point succinctly: "The establishment of the we in common perception is the simplest form of what Husserl calls the Vergemeinschaftung der Monaden: when two subjects confront one another and stand in relation to the same objects they form, to that extent, a rudimentary community that can itself be considered as performing an act (cogitamus) through 'its' diverse (and in this case simultaneous) presentations." (Carr 1973, 30) See also Carr 1986 and, critical of Carr's ingenious cogitamus-conception, Chelstrom 2013, chap. 3, as well as Zahavi (forthcoming); cf. also Schmid 2009, 34, and the useful discussion in Miettinen 2014.
} 
rocal" from "unilateral" or "one-sided" empathy (wechselseitige and einseitige Einfühlung; Hua XIV, 133, 135, cf. also ibid., 198f. and XIII, 98). Furthermore, social acts are founded upon distinctively communicative acts; as such, they build the foundational basis of agreements, collective acceptances, and, eventually, collective intentionality proper, though, again, they must be distinguished from the latter. Importantly-and, here, we have another difference to empathy - part and parcel of what makes such communicative acts distinctly social acts is that they have a specific normative content. In order for a social act to be successful, a subject's intentional act ought to be acknowledged by another subject and, possibly, the latter ought to be assisted in the fulfilment of the former (cf. Hua XIII, 98; XIV, 166f.).

(3b) Interestingly, in this connection, Husserl refers to something akin to what is currently a much-discussed phenomenon: joint attention (cf. Eilan et al. 2005). Thus, somebody may 'guide' the attention of another by signalling, pointing, or, guiding in an even more implicit way, e.g., by throwing a piece of wood in her direction. The other might then apperceive my action as expressing my intention to communicate something. Here, a shared background of understanding each other's communicative intention constitutes the attentional link (cf. Hua XIV, 167f.).

Consider that the foundational relations holding between these levels of sociality notwithstanding, there are various interrelations and interpenetrations between them. For instance, though empathy builds the basis of all other constitutional layers of social reality, empathy can be rightly said to be, in turn, an instance of the typicality of shared experiencing or, more generally, the common lifeworld (cf. Chelstrom 2013, 172). Similarly, social acts are performed against the background and are instance of the shared lifeworld, but also coconstitute what Husserl calls the universal "communicative plurality/community" of subjects (kommunizierende Vielheit/Gemeinschaft, Hua XIV, 74, 173, 197ff.). In this respect, the relations between (1), (2) and (3) as well as, incidentally, (4), should be construed not so much in the order of some foundational hierarchy but, rather, as interdependent moments of a complex constitutional process.

What Husserl has established up to this point is that the essentially social lifeworld comprises not only socialized individuals and intersubjective I-Though relations, but, also, social pluralities. Moreover, the lifeworld, for Husserl, is but the shared horizon of the universal community of subjects. Schematically, the three processes of socialization and communalization discussed so far can be epitomized thusly: no individual person without another individual and, eventually, without a community of persons; no objectivity of experiences without the transcendental We; and no proper social relations without explicit sociocommunicative acts.

(4) Having said this, it is crucial to distinguish from empathy, from the domain of the transcendental We, as well as from social acts the more specific socio-ontological domain that comprises those higher order communities that have a proper 'intentional life', or even a 'mind of their own' (Pettit 2003; List/Pettit 2011). Only here do we reach the level of CI. CI presupposes, but significantly differs from, intersubjective, social, and communal intentionality, to wit, regarding its subject, object and content.

On the face of it, the general structure of integration here is rather similar to social acts, in that the intention of one or more individuals functions as a motivational property, or a motif (Motiv) for another individual's intentions (Hua XIII, 104, XIV, 169). However, in con- 
trast to typically asymmetrical social acts, CI is based on mutual interest. Thus, the interlocking' of the motivational properties of one's intention into another's is occasioned both because of, and with a view to, a collective goal (the intentional object), eventually resulting in a collaborative endeavour to bring about that goal. Moreover, above and beyond the mere socio-communicative processes involved in social acts, we chiefly have practical-intentional, volitional and agential components involved here. Consider further that the constitutional relation is, just as in the case of social acts, not a one-way dependence but, rather, a correlation. Accordingly, the intentional properties of "practical communities of will" and, even more so, of higher order persons, may have reciprocal, or feedback effects on the individuals constituting of such. This typically happens through their "sedimentation" in the experiences and attitudes of the individuals involved via habits, tradition, or culture (e.g., Hua XIV, 222232). $\cdot{ }^{14}$

To get a more precise idea of Husserl's view on the structure of CI proper, it is worthwhile to quote a longer passage, in which, as I contend, he anticipates in nuce much of contemporary analytic accounts.

"A community of will, consent (Einverständnis) may then also be mutual, resulting in a mutual agreement (wechselseitige Vereinbarung). I satisfy your desire if you satisfy mine (...). Furthermore: We both want something to happen, we 'jointly' ('gemeinsam') take a decision, I do my respective part, you do yours. Etc. $S_{1}$ and $S_{2}$ want $G$, but not each of them separately, for their own sake, but $S_{1}$ wants $G$ as something that is equally wanted by $S_{2}$, the will of $S_{2}$ is part of what is willed by $\mathrm{S}_{1}$ (der Wille des $\mathrm{S}_{2}$ gehört mit zum Gewollten des $\mathrm{S}_{1}$ ) and conversely. The fact that $\mathrm{S}_{1}$ realizes $\mathrm{D}_{1}$ and $\mathrm{S}_{2} \mathrm{D}_{2}$ is, in turn, comprised in the volitions of both, comprised as 'means' (in a broader sense), or, as part of what belongs to the realization (als zur Realisierung gehörig), and, originally, to the intention (Absicht)." (Hua XIV, 170) ${ }^{15}$

To those familiar with the analytic literature on CI, this and other similar passages (cf. sec. 3) will certainly read somewhat untidily. So, what, exactly, is Husserl telling us here?

To be sure, given the central conceptual distinctions underlying analytic accounts of $\mathrm{CI}^{16}$, specifically, as to where one ought to 'tie in' the collectivity - a.) in the content or object, b.) the mode, or c.) the subject of collective intentions - one has a hard time with assessing Husserl. However, this is not so much due to a failure of having understood clearly the points at issue but, rather, to his very conception of collectivity and collective intentionality. Indeed, as I shall argue below (sec. 3), collectivity, for Husserl, is holistically built into the intentional content, object, and the mode, as well as the ab ovo communalized subjects, or the higher order collective subject of CI. ${ }^{17}$ Hence, as we shall see, Husserl not only circumvents any charge of atomism or solipsism, but, moreover, he eventually avoids the pitfalls of circularity in ex-

\footnotetext{
${ }^{14}$ Husserl even suggests that contracts and (explicit) agreements may have such sedimentation of "habitualized validity" (babituelle Geltung), which normatively binds the respective parties in meeting and fulfilling the commitment, cf. Hua Mat VIII, 334. For Husserl, the clearest and strongest form of a 'habitualized identification' of the affective/sensate and volitional subjectivity (babituelle Identifikation der Gemüts- und Willenssubjektivität), without explicit agreement or any kind of "concessions" are "spiritual love" and "love communities" (geistige Liebe, Liebesgemeinschaft) (Husserl 1923, 209). On the concept of "habitual volitional directedness" (babituelle Willensrichtungen), see Hua XXXIX, 389, on 'sedimentation', esp. Hua XLII, 39ff., 62ff.; cf. also Moran 2011.

15 Similar descriptions can be found at a number of places in Husserl's research manuscripts; for other telling passages, see, e.g., Hua XXXIX, 389 or Husserl 1923, 209.

${ }^{16}$ For excellent overview articles, see Tollefsen 2004, Roth 2011 and Schweikard/Schmid 2013.

17 For a similar line of interpretation, see Caminada 2011, 68f.
} 
plaining the jointness of collective intentions with reference to already-collective intentional engagements, a charge that has typically been directed against 'collective acceptance' or 'joint commitment' accounts of CI (cf. Tollefsen 2002, 2004; Schmid 2005; 2009). Before lending support to this interpretation, however, we have to get an initial understanding of the most compelling alternatives currently at our disposal.

\section{Current Accounts of Collective Intentionality}

In contemporary analytic theory of action, there is a widespread consensus that there are intrinsically collective intentions, such that they are irreducible to a mere summation or aggregation of individual intentions with the same intentional content or object. Within this nonsummative camp, one finds roughly four different models of explanation of CI:

(1) The first aims at explaining the sharedness of intentions in collectivity intentionality in terms of collective intentional contents. According to this model, joint agency is constituted by "appropriately interlocking" or "meshing" individual intentions with an aim toward a shared goal and common knowledge thereof. A key proponent of this view is Michael Bratman (1992, 1993, 1997). Bratman holds that two subjects A and B jointly intend to J, iff (i.) A and $\mathrm{B}$ respectively have an intention that we $J$, (ii.) A and B intend to $J$ "in accordance with" and "because of" (i.), A and B coordinate and "mesh" their "interdependent," "mutually responsive" and "mutually supportive" but individual "subplans" concerning their $J$-ing appropriately and in order to bring about a shared goal (in short, each does her part in J-ing), and, (iii.) A and B have common knowledge of (i.) and (ii.). This is a so-called distributive or individualistic account of shared intention. For, although the intentions bear reference to joint action and shared goals in the propositional content of the intentions ('I intend that we J'), the intentions remain distributed across the respective agents. Although there is an irreducibly collective content in each and every individual's intention, there is, as Bratman explicitly points out (1993, 123), no sharedness, or no shared intention, let alone some "fused" agent or volition, apart from the fact that individuals' intentions are appropriately interrelated (via (i.)-(iii.)).

(2) The second, equally distributive (and equally non-summative) CI-model is owed to a series of arguments advanced most prominently by Searle $(1990,1995,2010)$ and Tuomela (2007). Although their accounts differ in detail, ${ }^{18}$ they both share the assumption that collectivity must be (irreducibly) built into the very (we-)mode (Tuomela 2007), or, as Searle puts it, into the "sense of collectivity," the "sense of doing, (wanting, believing, etc.) something together" (Searle 1995, 24f.). According to this account, the very mode of my J-ing is constitutively affected by the fact that my J-ing is part of our J-ing. This shift from the content to the mode of CI is best brought out by contrasting Bratman's collective intentions, which supervene on the interlocking of intentions of the form ' $I$ intend that $w e J$ ' and 'You intend that we $J$, etc., with Searle's 'we-intentions' or Tuomela's 'we-mode' intentions, where collectivity is constituted by intentions of the form '(I) we-intend that we $J$ and '(You) we-intend that we $J$ ', and where such intentions, respectively, cause each of us to perform actions with view to a shared

\footnotetext{
${ }^{18}$ For some of their disagreements, see, e.g., Searle 1990 vs. Tuomela/Miller 1988 and Tuomela 1995; cf. also Tuomela 2013, 83ff.; however, Tuomela has suggested that Searle's view is well amenable to his own 'we-mode' account (Tuomela 2007, 100). Importantly, Tuomela (2007, 2013), unlike Searle, explicitly allows for groups as such to have we-intentions (as well as group beliefs, values, etc.), i.e., full-fledged group intentionality.
} 
goal. ${ }^{19}$ As Searle points out, a chief reason for this shift from the content to the mode is that it accounts for the fact that, in cooperative activities, typically, one's intentions have a different content than those of another agent, and, yet, they can well be said to partake in the same intentional activity. For example, I intend to play the piano, and you intend to play the violin; at the same time, precisely by each of us intending our own (different) actions, we may intend to play a duet together (Searle 2010, 44f.). All we need here is a mutual understanding that we are partaking precisely in a joint activity, whereby each of us is committed to do her part in bringing about the shared goal. Similarly, Tuomela holds that joint intentions constitutively entail that each participant "we-intends to bring about" or "sees to it" that an action or state is brought about jointly with other agents (Tuomela 2005, 330).

(3) In contrast, according to Gilbert's non-summative and non-distributive "plural subject" account, two or more individuals share an intention to $J$ if and only if they are "jointly committed" to intend as a single body to J (Gilbert 1989, 2003, 2006, 2009). As the label already indicates, this account lays stress on the subject of CI. More precisely, according to Gilbert's view, joint commitments constitute a plural subject, who is the proper subject, if not the 'bearer' (the "single body") of the collective intention. Crucial for Gilbert's proposal is the technical concept of joint commitments, which is the glue of CI, binding individual subjects to form a plural subject. In terms of a telling metaphor, what individuals do when they jointly commit themselves is "pooling their wills" (Gilbert 1989, 196f.). Importantly, Not only do joint commitments contrast with "personal commitments" (possibly to a shared goal), but, moreover, they are also neither a "conjunction" nor a "concatenation" thereof. Instead, they are "in an important sense simple or singular" (Gilbert 2006, 8). Joint commitments imply that the parties see to it "as far as possible to emulate, by virtue of the actions of each, a single body that intends to do the thing in question" (Gilbert 2009, 180). Precisely by doing so, the parties are jointly committed to the intentional action such that, unlike in the case of personal commitments, none of the parties can suspend the obligation thus created separately, not even the aggregate of the respective subjects, each taken separately.

(4) Lastly, in opposition to all three previous accounts and primarily directed against Searle's methodological solipsistic and internalist framework (cf. Meijers 2003; Schmid 2003), there are those 'relational' accounts of CI that stress the importance of normative (Meijers 2003) or non-normative, conative and affective (Schmid 2005, 2009) social interrelations between individuals. Relationists aim to counter the imminent charge of circularity, addressed to those who explain CI by some mechanism (essentially collective acceptances à la Tuomela, or joint commitments à la Gilbert) that presupposes individuals as already partaking in some joint activity. Consequently, some have argued that if CI presupposes collective acceptance or joint commitments, then these, in turn, cannot be explained by reference to isolated, solipsistic individuals but, rather, must make reference to certain (normative) relations (of obligations, rights to corrections, etc.) that hold between them. CI, according to this view, are not states of individuals tout court, but "states of related individuals" (Meijers 2003, 181). As Schmid puts it in a yet more radically relational vein: "Collective intentions are not intentions of the kind anybody has - not single individuals, and not some super-agent. For collective intentionality is not subjective. It is relational. Collective intentionality is an intentionality which people share." (Schmid 2009, 44) In other words, there is no collective intentionality without individuals

\footnotetext{
${ }^{19}$ For an illuminating critical elaboration of the contrast between Bratman and Searle, see Schmid 2005, 230ff.
} 
who we-intend (pace Bratman), but we-intentions are only what they are when individuals relate to another accordingly (pace Searle); indeed, they are nothing but relatedness (cf. Schmid 2005, 239f.).

\section{Husserl's Alternative Account}

Where does Husserl stand in this quadripartite conceptual landscape? As previously stated, I contend that Husserl's account of collective-let alone intersubjective, social or communalintentionality cannot be easily harmonized with any of these aforementioned accounts; if anything, it is, pace Schmid (2005), closest to the radical relationalists. Moreover, the commonality involved in practical and theoretical CI, for Husserl, is irreducible to the conjunction of (propositional) content, (we-)mode, and (plural) subject, nor is it constituted by either of them separately. Rather, it is a constitutional result of the above outlined, multi-layered process of communalization, beginning with empathy, advancing to the sharing of a weperspective and the corresponding constitution of a common lifeworld, and concluding with higher order persons. It is in this sense that subjects of CI, phenomenologically viewed, are $a b$ ovo communalized, that they are subjects who always already stand in social relations to one another. Note, again, that this interpretation of Husserl's CI-model, for what its worth, owes its credence, not to the textual evidence of Husserl's work on the issue of CI alone, but, rather, to his systematic account of the foundational structure and the gradually evolving layers of social reality as a whole.

Given the presentation of the four main types of theories of CI above (sec. 2), however, it should be clear that Husserl's own account resonates with a number of insights among each of them. For example, Husserl seems to agree with Bratman in that part of the (propositional) content of the parties' intentions or volitions is the shared intention, or the jointly intended, volitional goal and, also, that the parties rely on the intentional subplans of each other (Hua XXXIX, 387) to "motivate" one another's intentions (Hua XIV, 171) and, eventually, play their own respective parts in bringing about the shared goal. Compare, again, the quote above from Husserl: "I do my respective part, you do yours (...) that $\mathrm{S}_{1}$ realizes $\mathrm{D}_{1}$ and $\mathrm{S}_{2} \mathrm{D}_{2}$ is (...) comprised in the volitions of both, comprised as 'means' (...)", to what Bratman says about "shared cooperative activity" (SCA): “(...) for our J-ing to be SCA I must intend that we $J$ in part because of your intention that we $J$ and its subplans", wherein this requires, among other criteria (such as commitment to mutual support), that "each agent treat [s] the relevant informations of the other as ends-providing for herself" (Bratman 1992, 100, 102). Moreover, according to what is an admittedly charitable reading, even on the terminological level, there is much concordance when Husserl speaks of the "interweaving" or "meshing" of interests and volitions (Willens-/Interessensverflechtung; Hua XIV, 170; XXXIX, 386) or of "intentional intertwinement," and Bratman, too, of the "meshing" or "interlocking" of intentions. But, surely, and here ends the comparison with Bratman, if such interlocking is successful, then, for Husserl, the result is a genuine we-intention (à la Searle), where the jointness is built into the very mode ${ }^{20}$ of individuals' intentions. Furthermore, if the integration is more robust than

${ }^{20}$ Here, it should be noted that the concept of '(we-)mode' in the present context is used in a broader sense than Husserl does so when he speaks of modes of conscious experiences (Bewusstseinsmodus; cf. Hua X, 79, 
a mere ad-hoc-collaboration (of the SCA-sort), then we have higher-order collectives, which have, rather than only Bratman's shared intentional contents and goals, full-fledged we-mode group intentions (à la Tuomela).

There are also a number of places where Husserl closely approximates Gilbert's plural subject account and seems, generally, to come closer to a joint commitment and/or a collective acceptance view. Consequently, in a successful meshing of intentions, Husserl stresses the prevalence of a proper plural subject of volition, the so-called "community of will," and its (normative) role in enabling, or enacting, collective agreements over 'personal' intentions and goals. Above and beyond the aforementioned ones, here is another telling passage in support of this view:

\begin{abstract}
"Associations (Vereine), communities of will (Willensgemeinschaften). The goal of the association, being the goal aimed at by all, 'communally' intended ('gemeinschaftlich' erstrebt). Agreement. Each assuming 'her part' in realizing it. An agreement upon a goal to be achieved jointly, however, is not an association. (...) An association becomes a sort of subject of volition (eine Art Willenssub$j e k t)$, and the member of the association is commissioned (beauftragt), or acts without a commission by herself, but not as a private person, but as a member in the spirit (im Sinne) of the association. The appropriately directed will is will as a member. The original will is streaming into the center, as 'will of the association' ('Vereinswille): on becoming a member of the association, and also afterwards, it is at the same time an individual volition (Individualwille), yet emerging from that center, and that means, not merely a private volition but a member-volition (Mitgliedswille)." (Hua XIII, 108).
\end{abstract}

Notice, however, the following crucial difference to Gilbert or any collective commitment or agreement view, a difference that also allows Husserl to parry objections of circularity of the sort mentioned above: ${ }^{21}$ Thus, quite unlike current proposals, at a number of places, Husserl submits that collective acceptance, agreement, or commitment typically is a result and not, in any substantial sense, a constituent of collective or group-intentionality (cf. Caminada 2011, 68). We find the most explicit formulations of this view in those two longer quotes cited above (Hua XIV, 170; XIII, 108), where Husserl says that a community of will may "result in mutual agreement," or that such an agreement does not, eo ipso, amount to an association. Accordingly, Husserl declares that "not all communal achievements (Gemeinschaftsleistungen) emerge from agreements" (Hua Mat VIII, 334; cf. also XXXIX, 385ff.). Moreover, mutual or collective agreements, for Husserl, even if in place, are not necessarily made explicit. Indeed, typically, agreements are made against a more general yet not any less fundamental background of commonality. Thus, Husserl localizes agreements (Vereinbarungen) within the "unitary field of dissent and possibilities of consent (Vermöglichkeiten der Einwilligung)," or "a horizon of unanimity" (Horizont der Einstimmigkeit) (Hua XXXIX, 396; cf. also 385ff.).

367f.; Hua XXIII, 407; Hua Mat VIII, 270), essentially referring to the so-called 'qualitative' intentional and/or doxastic modes such as belief, doubt, memory, re-presentation, and/or imagination.

${ }^{21}$ For another line of phenomenological criticism of Gilbert's plural subject account, according to which individuals may - phenomenally - well have shared experiences without, in fact, there being a plural subject or a (reciprocal) joint commitment satisfying the respective individual's experiences, see Chelstrom 2013, 147-155. Though I find Chelstrom's criticism convincing (see also Szanto 2014b) here, I am not, however, dealing with the subjective phenomenology of shared experiences. Cf., critically of Gilbert from a phenomenological point of view also Schmid 2005 and 2009. 
Finally, as to the relational accounts, in an important sense, Husserl concurs with such accounts. For Husserl, too, holds that some background of commonality or sharedness must be always already presupposed in order for individuals to engage in CI in the first place, and that this is constituted, not by pre-social individuals, but, rather, by intrinsically social relations among such individuals.

Given this reassessment of Husserl against the contemporary proposals, I propose the following systematic reading of his view on CI:

Two or more subjects $S_{1}, S_{2} \ldots S_{n}$ jointly intend to $J$ if

(1) the 'intentional lives' of $S_{1}, S_{2} \ldots S_{n}$ are communalized via mechanisms of intentional implication (i.e., essentially via empathy, shared typicalities and habitualities of experiencing, or the commonality of a lifeworld and, possibly, via sociocommunicative acts);

(2) (some of) $\mathrm{S}_{1}$ 's, $\mathrm{S}_{2}$ 's ... $\mathrm{S}_{\mathrm{n}}$ 's intentional properties (perceptions, cognitions, affections, volitions, etc.) motivate each other's own;

(3) $\mathrm{S}_{1}$ 's, $\mathrm{S}_{2}$ 's $\ldots \mathrm{S}_{\mathrm{n}}$ 's individual intentions to $J$ are intentional part and parcel of each others intentions, such that it is an intrinsic part of the intentional content of $\mathrm{S}_{1}$ 's intention that there is a goal shared by $\mathrm{S}_{2},(\mathrm{SG})$, and that $\mathrm{S}_{1}$ is intending $\mathrm{SG}$ as it is intended by $\mathrm{S}_{2}$ (and the same goes for $\mathrm{S}_{\mathrm{n}}$ );

(4) possibly, there is an explicit collective agreement or a joint commitment regarding SG, and/or to (5), and/or a joint decision to J;

(5) $\mathrm{S}_{1}, \mathrm{~S}_{2} \ldots \mathrm{S}_{\mathrm{n}}$ assume each its own part in bringing about $\mathrm{SG}$.

Consider that, in the central clause (3), 'part and parcel' not only refers to the sharedness of intentional contents and modes, but also means, as Husserl indicates in the quoted passage, in a still stronger sense and in terms of something close to 'conditions of fulfilment', that $\mathrm{S}_{2}$ 's intention "belongs [as 'means' (in a broader sense)] to the very realization" (Hua XIV, 170) of $\mathrm{S}_{1}$ 's intention.

The upshot, then, is this: Collectivity, or jointness in collective intentions, for Husserl, is constituted by the appropriate intentional integration of the intentional, goal-directed, normative, volitional and practical properties of the mental life of always and already socialized and communalized individuals. The integration, in turn, is brought about, not so much through mere collective agreement (as for Tuomela), nor by the mere interlocking of individual subplans in attaining a shared goal (as for Bratman), but, rather, by the very intention through which one subject functionally enters, or is realized in, the intentional content of another subject as joint 'means' to attain a shared goal. The shared goal, the object correlate of the respective intentions, is, thus, 'represented', as one might phrase it in Searlean terms, as the same intentional content in both intentions. Hence, the result is a genuinely we-mode volitional act.

Now, if this integration is robust enough, then what is thus constituted is a so-called practical community of will, or a fully-fledged higher order person (HOP). Moreover, if this is the case, then HOPs - above and beyond the collective intentionality of jointly engaged individuals-have a we-mode group intention to G. Consequently, in such cases (and only in such 
cases, mind you), the communalization does not stop at (5), but, instead, assumes more robust forms. What we have, then, is this:

(6) Founded on (1)-(5), and quite possibly on customarily distributed shared intentional functions (via habits, traditions, culture, etc.), shared values, etc., and a more or less explicit integration of intentions, volitions, values and interests of $S_{1}, S_{2} \ldots$ $\mathrm{S}_{\mathrm{n}}$ (essentially as in (4)), there is a diachronically-robust sphere of commonality and shared 'intentional action patterns' vis-à-vis SG.

(7) Founded on (6), and on the 'integrate'22 of the intentions of the members $S_{1}$ and $S_{2}$ $\ldots \mathrm{S}_{\mathrm{n}}$, there is a HOP, who is the proper subject of collective intentionality.

(8) HOP intends to $G$.

Now, provided this view, we arrive at Husserl's robust anti-individualism, a thesis that pertains less to the intentional nature of individuals or the ontological nature of social entities and more to the formal structure and the subject of collective intentionality. More specifically, consider two related but distinct variants of anti-individualism, both of which, I contend, Husserl, in fact, endorses:

Formal Anti-Individualism: There are intentional states and (practical) intentions that have a first-person plural form or mode (i.e., we-intentions, or we-mode intentions).

Subjective Anti-Individualism: We-(mode-)intentions possibly, to wit, under suitable (sociopractical) integration of their respective subjects, have a supra-individual (higher order) subject of intention. ${ }^{23}$

Thus, in the first type of anti-individualism, the issue is whether the form or mode of collective intentions (we-mode or we-intentions) is reducible to a set or aggregation of reciprocal ' $\mathrm{T}$ intentions.' The second concerns the question of whether the class of possible 'bearersubjects' of intentions is restricted to individuals or, rather, may range over collectives. While most current authors would advocate the weaker, formal anti-individualism (Searle, Tuomela, and, obviously, Gilbert, although with the notable exception of Bratman, against whom it is mainly directed), the latter, stronger, subject anti-individualism seems deeply problematic to most participants of the CI-debate, with the few prominent exceptions of Gilbert and Pettit, and his co-authors. ${ }^{24}$ Obviously, even the firmly anti-individualist relationalists (Schmid and Meijer) explicitly reject subject anti-individualism.

\footnotetext{
22 The concept of a 'social integrate' is owed to Pettit 2003; for more on this, see below .

23 This important distinction is introduced in Schmid 2005, 189, 226ff. and 2009, 34-44, 116; cf., critical of a subjective anti-individualistic interpretation of Husserl, Chelstrom 2013, 78, $110 \mathrm{ff}$.

${ }^{24}$ Notice that both Gilbert and Pettit (and co-authors) employ a different terminological framework. Accordingly, for Gilbert, the endorsement of both formal and subjective individualism would amount to what she labels "singularism" and which, to be sure, she rejects (cf. Gilbert 1989, esp. 12f.); Pettit \& Co., in turn, would label the position at issue not anti-individualism (see Pettit's construal of the claim that our individual intentional psychologies are, in some way or another, compromised by social regularities, whereas this, in my terminology, amounts to collectivism), but, rather, similar to Gilbert, "anti-singularism” (cf. esp. Pettit 1993 and Pettit/Schweikard 2006).
} 
Here, then, we see how markedly Husserl's alternative theory of CI contrasts with most of the current proposals. Yet, is formal-cum-subject anti-individualism not precisely too strong of an alternative?

\section{Two Objections: Content/Vehicle-Fallacy and Collective Consciousness}

At this point, some may wonder whether Husserl is not at risk of committing a sort of vehicle/content-type fallacy. In the present context, the fallacy would be to infer from the jointness of the content or mode of CI the existence of one-potentially supra-individual and/or emergent—vehicle or bearer of those we-intentions (e.g., a HOP or similar). This objection may also be voiced in terms of a fallacy of composition, or a homuncular fallacy (cf. Chelstrom 2013, 30, 58). In a similar yet more serious line of objection, Schmid has argued that Husserl would simply take over his egological categories and project them onto higher order entities. By evoking some higher order collectivities, mapped onto the structure of their lower order constituents (transcendental egos), Husserl would, somewhat ironically, be at fault on ground of both methodological individualism/solipsism and of a dubious sort of collectivism (Schmid 2000, 17-27). ${ }^{25}$ Furthermore, a second, related concern might be that Husserl, at a number of places (see below), suggests that HOPs have a subjectivity of their own, and, what is more, that he attributes conscious and even self-conscious properties to them. The common charge in both objections is that, by postulating a collective subjectivity with a consciousness of its own, one would reify intersubjective relations. Another way to square these two objections is nicely put by Pettit's criticism of the Hegelian notion of Volksgeist, or a Durkheimian collective consciousness. According to Pettit, "there is a notorious ambiguity in any such notion, for it may refer to a people's thinking or mind as well as to a people's thought: to a collective state or medium of consciousness as well as to a collective content" (Pettit 1993, 168).

However seriously we must take this double objection, (and all the more so, since I believe that no account of group personhood or group mindedness can sensibly accommodate any sort of properly speaking 'collective (self-)consciousness' (cf. Szanto 2014a)), I contend that these objections are ultimately misguided. In particular, Husserl's multi-layered 'social integrate' (Pettit 2003) account of HOPs should be construed as a 'non-entity', or even as a 'no-ownership view' of group persons, which allows him to undermine the force of theses objections.

As to the first, 'projectionist' objection, consider the following two requirements, which any adequate theory of plural or collective subjects (CS) must at least fulfill, be they spelled out as group agents, group persons or group minds, all concepts that Husserl himself employs:

(1) Plurality Requirement: CSs, qua collective subjects, must be construed so as to account for the fact that they 'comprise' a collective or a plurality of individuals (which also allows for a certain 'intentional variation' in their mental life). ${ }^{26}$

\footnotetext{
${ }^{25}$ Note that collectivism, here, is not tantamount to some version of intentional or normative collectivism (cf. Pettit 1993 and Szanto forthcoming a), but to the more specific claim of collectivizing subjects of CI.

${ }^{26}$ Different formulations of this requirement can be found in Gilbert 1989, Mathiesen 2005 and Chelstrom 2013.
} 
(2) Integrity Requirement: CSs, qua collective subjects, must be construed so as to account for the fact that they are not just a simple collection, aggregate or plurality of individuals, but have a certain integrity as a subjectivity with its own intentional point of view.

How can Husserl's theory of HOP accommodate both requirements? To start with, it is crucial to note that the process of intentional communalization outlined above constitutes distinct types of subjects of collective intentions. Though Husserl, admittedly, fails to provide a systematic taxonomy of the variety of subjects of CI, one can devise the following four main types of social subjectivities: a.) "communicative, integrated personal pluralities" (kommunikative, verbundene Personenvielheit), b.) "practical communities of will' (praktische Willensgemeinschaft), c.) "supra-personal subjectivities" (überpersonale Subjektivitäten), and d.) full-blown "higher order persons" (Personen höherer Ordnung), or the infamous 'communal minds' (Gemeingeist) (Hua XIV, 169, 197, 200f.). ${ }^{27}$ Whether we have instances of one or another type of collective depends, essentially, on how 'deep' the process of communalization into the intentional life of the respective individuals (as to their affective, cognitive, normative, etc. properties) reaches and how robust the intentional integration is. For example, a HOP (d.) can only be instantiated in "distinct cases" of communal volition and action (Hua XIV, 205, 219f.) and not on the purely experiential or communicative domain, however much they may be integrated.

Now, this multi-layered account of the subject(s) of CI is a further, majorly important advantage of Husserl's account over standard current models, ${ }^{28}$ for it captures, above and beyond the distinction between intersubjective, social, communal and collective intentionality, the most salient phenomenological differences between various types of communalization within the domain of CI. This multi-layered feature is also encapsulated in the very concept of 'higher order.' Without there being a sort of teleological hierarchy of collective agents, Husserl's theory of foundation equips us with all necessary resources for the analysis of the gradual evolvement of ever more complex and, at the same time, ever more integrated social entities. ${ }^{29}$

Thus, there is a crucial distinction between various types of intentional integration of subjects of CI according to the levels of social communalization (Stufen der sozialen Vereinigung). In fact, theses levels of integration, in terms of their intentional subject-'poles,' roughly correspond to the distinction between intersubjective, social and collective intentionality. We can discern three such types of social subject-poles: (i.) essentially empathy-based intersubjectivity with "non-integrated individual subject-poles" (vereinzelte/isolierte Pole von Individuen), (ii.) mul-

\footnotetext{
${ }^{27}$ As to Husserl's cautioning against collectivistic misuses of these concepts, it is interesting to note that, while he continued to use the term higher order persons after Hitler's takeover in 1933, he explicitly rejected the term Gemeingeist and those with similar connotations as "mysticism" and "mythology"; see Caminada 2011, 60 and Husserl's manuscript K III 1, p. 9 (quoted in Toulemont 1962, 177). At any rate, the more fine-grained semantics of Husserl's use of the concept of supra-individual social entities, as well as the examples that Husserl gives in support of them, is vertiginously complex. He uses whole series of interrelated conception, acknowledging at one point that he would "name everything mixed together" (Hua XIV, 220); see, critically, Schmid 2001, 17ff.; see, relatedly, also Szanto forthcoming a.

${ }^{28}$ Cf., however, a similar but slightly different distinction recently put forth by Helm (2008), namely, between "plural intentional systems," i.e., merely instrumental, goal-directed collectives, and "plural robust agents," i.e., the "subjects of import," the latter entailing a "shared evaluative perspective," and also shared emotions.

${ }^{29}$ For a concise discussion of the sense of 'higher' in the concept of higher order persons, see Allen $1978,75$.
} 
tipolar (communicative) communities, which may constitute more or less robust, proper "systems of poles" (Polsysteme) and, finally, the domain of communities, such as "love" or "ethical communities," 30 with habitualized and robustly synthesized subject-poles (Polsynthese) (Husserl 1923, esp. 218ff.; cf. also Hua XIV, 173ff.). ${ }^{31}$

Secondly, one should not loose sight of the fact that the relation between individuals and higher order persons is a foundational one, and that it is not a relation between individuals but, rather, between complexities or collections of individuals. Individuals and HOPs do not relate to one another as individuals relate to other individuals. Accordingly, it is a set, or better, a multiplicity of persons (Personenvielfalt) that is the foundational "substratum" of higher order persons (Hua XIV, 200f.; cf. Hart 1992, 256f.). Thus, even though there is a robust unity to such multiplicities, such that HOPs can be said to synthesize their individual members, the relation between them is not a simple mereological containment, for the individuals remain distinct, or separate, in two ways: first, they are individually distinct from one another and never simply 'fuse' intentionally into one another when they partake in the same (supraindividual) mental life; 32 secondly, the personhood of individuals remain individuated by themselves, i.e., they continue to be, even if "unified" (geeinigt), "individual persons" (Hua XIV, 202). And, precisely in that sense, individuals always remain distinct and independent from any supra-individual subjectivity. As Husserl succinctly puts it: "[Communal subjectivity] is a many-headed unified subjectivity" (Hua XIV, 220; cf. also 218).

Moreover, intentional implication and integration, for Husserl, never amounts to something like intentional, let alone 'real' (reell), fusion. Quite the contrary, in an anti-collectivist vein Husserl, emphasizes the fact that intentional integration is not only strictly compatible with plurality and separateness of the mental and personal life of the respective individuals, but, moreover, that this very separateness is itself the transcendental condition of possibility of any social integration (cf. also Zahavi 2001, 75ff.):

"In a certain sense, the individuality of souls (Seelen) means an unbridgeable separation - thus a being-different-than-the-other (Anders-Sein) and a being-external-to-one-another (AuseinanderSein) (in a logical not a spatial sense), which can never develop into a continuous connection, into a connection that would be a continuous flowing-into-one-another (Ineinanderfließen) (...). On the other hand, this separation does not preclude that the monads 'coincide' (sich 'decken), in other words, it does not prevent them from being able to be in community with one another, and indeed, this separation is the condition of possibility of such [coincidence and community].” (Hua XV, 335)

Yet, however distinct and however multiple, the concept of socio-practical integration must be taken literally. As already noted, Husserl is very explicit that higher order collectives are not simple aggregates, but "social unities" in the full sense. More specifically, HOPs "consti-

\footnotetext{
30 To some readers, Husserl's phenomenology of sociality may sound all too harmonious, as if the "commerce" of individuals (Hua XIV, 124) would not allow for dissent or worse. None of the above, however, precludes such. Quite the contrary, Husserl notes that dispute, hatred, fights, etc., essentially belong to and take place within the very process of communalization, cf. Hua Mat VIII, 334; XXXIX, 396; Husserl 1923, 209.

31 See also the congenial discussion of the Husserlian distinction between "simple intersubjectivity" (simple intersubjectivitè), "pole-systems" (système de pôles) and "pole-synthesis" (synthèse de pôles) in Toulemont 1962, $311 \mathrm{f}$.

32 Cf. also the famous passage in the Crisis (and this passage, ironically, has been often criticized as evidencing transcendental solipsism), wherein Husserl unmistakably states that "the primal I (Ur-Ich) (...) can never lose its uniqueness and personal indeclinability" (Undeklinierbarkeit)" (Hua VI, 188).
} 
tute not merely collections of social subjectivities, but coalesce into (schließen sich zusammen zu) a social subjectivity, inwardly organized to a greater or lesser degree, which has its common opposition pole (gemeinsames Gegenüber) in a surrounding world, or an external world, i.e. a world which is for her" (Hua IV, 196). If this is the case, then the multipolar, "many-headed," or "headless," social subjectivities integrate so as to become a unitary, yet higher order agent. ${ }^{33}$

Consider, however, that Husserl nowhere treats social integrates as some kind of substantial super-entities. Rather, they are functional and intentional poles of actions, thoughts, intentions, or values. In this respect, even if we have an instance of a we-mode synthesis of poles with a respective "synthesized personality" (Husserl 1923, 220), there is not an extra 'owner' of such poles (be it a supra-individual one) above and beyond the very social integrate of individuals. "Common minds" are, as Husserl points out, "not something besides [the minds of a plurality of bodies, standing in physical relationships, something required for intercommerce], but an encompassing 'sense' ('Sinn) or 'mind', [an] objectivity of a higher level]" (Hua IV, 243). Again, this encompassing, or shared sense is not constituted by an extra-entity, over and above the individuals engaged, but precisely by the integration of each and every individual's first-person point of view into a first-person plural point of view.

Indeed, we find further ammunition for this interpretation in Husserl when he observes that HOPs are different, not only from mere intersubjective engagements in social acts, but also from multipolar communities, where individual members are each separately focused on a shared goal. In contrast, HOPs have their own pole of intentionality, analogous to the egocentred individuals, and, thus, are so-called "centred communities":

"The I-centeredness (Ich-Zentrierung) that is proper to each individual subject, can have, but has not necessarily a real analogue in the communalized intersubjectivity. One may speak of a social personality only if we can speak of a sort of I-centeredness vis-à-vis the individual subjects and of a persisting habituality (verbarrende Habitualität) of the centred community (zentrierte Gemeinschaft)." (Hua XIV, 405).

This very view, I contend, is an avant la lettre-formulation of an ingenious proposal in contemporary social ontology, namely, Carol Rovane's account of group persons and Philip Pettit's account of groups with minds of their own. The basic idea here is that group persons and agents are epistemologically distinct from their members, upon whom they, nonetheless, ontologically supervene insofar as they have their own 'rationally unified point of view' (Rovane 1998; Pettit 2003), their own 'intentional profile' (Pettit/Schweikard 2006) or 'vision' (List/Pettit 2011, 34). Importantly, this point of view may be epistemologically orthogonal and is, in any case, irreducible to each and every first-person point of view of the respective group members (cf. more detailed Szanto 2014a).

\footnotetext{
33 See Hua XXVII, 22: "Community is a personal, many-headed, as it were, and yet integrated (verbundene) subjectivity. Their individual subjects are 'members' (,Glieder'), functionally interwoven (funktionell miteinander verflochten) through various mentally unifying 'social acts' (I-Thou-acts, orders, agreements, activities of love, etc.), which link person to person. Occasionally, a community functions as a many-headed and yet in a higher sense 'headless': to wit, without being centered upon a unity of a subject of volition and acting analogously to an individual subject. However, it may also assume this higher form of life and become a 'personality of higher order' and as such perform communal achievements, which are not mere aggregate formations (Zusammenbildungen) of individual-personal achievements, but in the full sense personal achievements of the community as such, realized in its striving and willing."
} 
Now, what about a proper phenomenological point of view? Do groups have such, or are groups, instead, individuated exclusively by their rational, practical and intentional point of view? In other words, what about the conscious experiences of such centred communities? The question is all the more pertinent, given transcendental phenomenology's systematic claim about the constitutive correlation between intentionality and consciousness. For, if every intentional state is eo ipso a conscious mental state (cf. Szanto 2012), as this correlation indeed entails, one might wonder whether this equally holds for the intentional states of HOPs. So, given Husserl's general theory of the intentionality of consciousness, it seems as if Husserl's theory of CI would inevitably lead to the arguably untenable (cf. Szanto 2014a), claim that there were something like a 'collective consciousness'.

Yet, although Husserl, indeed, speaks of an "all-encompassing communal consciousness" (übergreifenden Gemeinschaftsbewusstsein) (Hua VI, 166) or "a unity of a supra-personal consciousness" (Hua XIV, 199), a "unity of a communal consciousness" (Hua XXVII, 21), and even goes so far as to attribute a "capacity of self-reflection," and a "self-consciousness in the proper sense" (Hua XXVII, 49) or a "“self-consciousness' of higher order” (Hua XIV, 220), surprisingly, he remains rather vague on how to flesh out the conscious and phenomenal properties of social entities. However, I contend that Husserl's scattered remarks allow for distilling his general view on the topic and, in particular, for defending it against the charge of any dubious construal of collective consciousness.

The decisive step down this road is to properly distinguish four different senses in which Husserl speaks of social and collective (self-)conscious properties: ${ }^{34}$

(1) First, we have a sort of 'empathic consciousness,' wherein individuals can be said to directly experience the consciousness of others. This sort of 'consciousness' may be controversial on other, independent epistemological grounds, yet amounts to no more and no less than what, today, one would call social cognition or knowledge of other minds and is, thus, not a true problem of any sort of collectivizing consciousness.

(2) Relatedly, we have what Husserl sometimes describes as an "all-encompassing communal consciousness" (übergreifendes Gemeinschaftsbewnßtsein; Hua VI, 166). This is founded on empathic consciousness and corresponds to the above-mentioned we-synthesis, whereby, via various intentional implications, each individual is experiencing the other, not simpliciter, but as experiencing the same world, i.e. the (objective) "world for us all" (Hua VI, 257ff.). Here, we have what Husserl also refers to as the "unification" (Vereinigung) or "coincidence" (Deckung) "of one consciousness with another". Though, significantly, "they necessarily remain separated" as "individual consciousnesses" on a higher, properly personal, level; as

\footnotetext{
34 The most sophisticated and critical phenomenological account of the concept of collective consciousness, as distinct from "supra-individual stream of experiences" (überindividueller Erlebnisstrom) is provided by Stein 1920, a study that was familiar to Husserl; on Stein, see Mulligan's contribution in this volume, Caminada 2010 and Szanto forthcoming b. The only contemporary author, to my knowledge, who argues for the possibility of collective consciousness (and, incidentally, against the conception of group minds), from, indeed, a phenomenological perspective, is Mathiesen 2005; however, what she has in mind is that "individual members" of a given collective, which complies with the plurality requirement above, "are aware of the contents" of their weintentions (Mathiesen 2005, 248). This, Mathiesen's “awareness condition," to be sure, is something to which Husserl, in fact, subscribes (cf., e.g., Hua XIV, 220f.), but which seems not to amount to any robust conception of collective consciousness proper; for a convincing critique of Mathiesen, see Chelstrom 2013, Chaps. 1-2, which represent the most thorough discussion of collective consciousness to date. See also Hart 1992, 269 for a congenial discussion of the self-consciousness of HOP.
} 
such, they can be said to converge into a "unity of supra-personal consciousness" (Einheit des überpersonalen Bewusstsein) (Hua XIV, 199; cf. VI, 166f.). From the context of the respective passages, then, it is rather clear that what is meant by these forms of consciousness is but a transcendental correlate of the intersubjective horizon of possible experiences of a universally shared lifeworld. True, Husserl sometimes, misleadingly enough, characterizes this coalescence as an integration into "a united stream of consciousness" (geeinigt qu einem Bewusstseinsstrom) (Hua XIV, 202f.). However, this should not lead one astray, for this "interrelation of consciousnesses" (Bewusstseinszusammenhang) (ibid., 200ff., 218) simply means that there is an intentional arguably of (shared) sense, just as there is on the level of individual consciousness (cf. ibid., 279).

(3) Next, there is a relatively innocuous sense of 'social consciousness,' which designates not a phenomenological consciousness proper, but, rather, a form of 'social identity,' a 'sense of membership' or 'belonging,' together with the correlative 'sense of duty' with respect to the traditions, values, etc. ${ }^{35}$ Husserl's use of such terms as "family" or "clan consciousness" (Familienbewusstsein, Stammesbewusstsein) (Hua XIII, 109) evokes this denotation, too. Incidentally, this roughly approximates the sense in which Durkheim first introduces the term 'collective consciousness', as the totality of common beliefs, values, etc. of the average members of a given community (Durkheim 1893/1922, 35ff.).

(4) Finally, and certainly most controversially, Husserl occasionally, and sometimes, indeed, in the very same passages concerning the other senses, most especially the second as enumerated above, invokes the notion of a sui generis higher-order (self-)consciousness (Hua XIV, 220; XXVII, 49). However, this ought not to delude us, for Husserl hastens to add to the same passages that all conscious acts of the community are founded upon and performed, qua acts of consciousness, by the acts of the respective individual members (Hua XXVII, 49). Moreover, from the context of these two passages, it is quite clear that what happens when HOPs are said to have self-consciousness is not simply that either some or all members become conscious of themselves being members of the given HOP, including any subsequent awareness of the normative and ethical obligations that this membership entails. In other words, acts of (self-)reflection of individual members may be communalized in the sense of individuals' self-reflective acts having a communal content, or being performed in the wemode (by individuals, to be sure). For example, somebody may perform self-reflection as a group member, i.e. in we-mode, by asking herself, "Are we right in believing this?" This, however, is nothing more than a sort of communal manifestation of individual subjects' selfreflective contents, namely, by virtue of those individuals performing full-fledged we-mode acts of self-consciousness (cf. Allen 1978). Concerning any alleged self-consciousness of HOPs 'themselves,' the passages under consideration evoke nothing other than a kind of ethical or normative 'stocktaking,' 'self-assessment' or 'self-determination' of its own rational point of view (Selbstwertung, Selbstgestaltung; Hua XXVII, 49). It is not, in any particularly compelling sense, some "pre-reflective plural self-awareness" (Schmid 2014; cf. Szanto 2014a).

To sum up, in none of these four senses of 'collective (self-)consciousness' do we have an instance of phenomenological (properly speaking) consciousness or self-awareness. Notwithstanding either some misleading formulations or the fact that Husserl fails to systemati-

\footnotetext{
35 Notice, however, that Husserl sometimes speaks of "social consciousness" (soziales Bewusstsein), not in this Durkheimian, but, rather, in the sense of what I list in (4.), cf., e.g., Hua XIV, 206.
} 
cally disambiguate the intentional, normative, rational and (quasi-)personal features of the mental life of communities and the respective concepts of higher order group persons, group minds, and collective and social consciousness, one does not detect, in Husserl, any genuinely problematic form of hypostasizing a collective bearer of consciousness or a giving way to the tendency of reifying conscious properties on the collective level.

\section{Conclusion}

If my systematic reading is fair, I hope to have established that Husserl has, above and beyond his theory of empathy, intersubjectivity and his social ontology, an avant la lettre theory of collective intentionality. However unsystematic and admittedly half-baked at some junctures, Husserl's account of CI foreshadowes all the relevant issues that, decades later, would be discussed in extenso in the analytic debates. Now, this fact alone, however unfamiliar it may be to most, does not make much of a difference, to be sure. What, then, do we gain from the specific Husserlian account? I wish to have shown that Husserl's account of CI has a number of advantages over current proposals, pointing to a more adequate understanding of the constitution and the structure of social reality.

Let us take stock of what I take to be the five key merits of the Husserlian account: (1) First, Husserl is, contrary to some critical commentators and in contrast to the virtually all current work in social ontology, adamant that social reality, at no level, is composed of presocial atoms but, rather, of ab ovo socialized individuals. (2) Secondly, this very starting point allows Husserl to devise a more complex and adequate theory of the constitutional and foundational layers of the process of socialization and communalization of individuals than what obtains in mainstream analytic social ontology. Verily, such a theory accounts for the fact that the socialization of individuals - i.e., their entering and entertaining intersubjective and social relations - and their communalization-i.e., their entering and entertaining collectives of various levels of integration - are but two aspects of the complex process of the constitution of an essentially common lifeworld. Moreover, Husserlian phenomenology allows for a fullyfledged 'intentionalist' description of communalization, a program often pointed to (e.g. by Gilbert 1989) but little expounded upon in contemporary social ontology. Thus, Husserl offers a more fine-grained description of the constitution of sociality, both on the (inter) subjective, as well as the collective level. Furthermore, such a description is not carried out from an external point of view (pace Mathiesen 2005, 242) in terms of some observable socioontological functions, structures or systems but, instead, from the first-person singular and plural perspective of the respective individuals and groups. (3) Accordingly, just as it does so in differentiating between intersubjective, social, communal, and collective intentionality, Husserlian phenomenology emphasizes, as a crucial addendum to contemporary models, the heterogeneous nature and multi-layered structure of social relations and collectives. (4) Regarding the nature and structure of collective intentionality proper, Husserl suggests, even if only in nuce, a highly original alternative to contemporary, predominate accounts of the same. This alternative yields a robust formal-cum-subject anti-individualism. It undercuts the need for deciding between tying in collectivity with either the subject, the mode, or the content of collective intentionality. Moreover, it renders dissuasive the circularity objection regarding the 
question of a foundational priority of collectivity over individual (we-)intentions. (5) Lastly, concerning the subject(s) of CI, a significant benefit of the Husserlian account is to offer, once again, a multi-layered account, thereby putting the subject of CI in its respective place, depending, essentially, on how deep the process of communalization into the intentional life of the respective individuals reaches (their affective, cognitive, normative, etc. properties). Of course, this, in turn, rests on those mechanisms through which such integration and communalization are achieved, as well as on how robust the social integration is. Finally, this multidimensional model of the respective subjects of CI helps Husserl to vindicate intentional anti-collectivism and, also, to block the alluring but erroneous tendency to reify subjectivity on the group level.

Overall, then, Husserl's theory of collective intentionality suggests a number of original solutions to the most salient problems and shortcomings of current accounts, and is, ultimately, better geared to handle the notorious complexities of social reality.

Acknowledgments Earlier versions of this paper were presented at University College Dublin (2012), the University of Graz (2013), and the University of Vienna (2013). On all of these occasions, I received valuable comments and esp. profited from discussions with Emanuele Caminada, Nicolas de Warren, Jo-Jo Koo, Dermot Moran, Sonja Rinofner-Kreidl and Dan Zahavi. I would also like to thank Tim Burns, Sophie Loidolt, Geoffrey Manzi, Franz Prammer and Gerhard Thonhauser, all of whom commented on the penultimate version, and, not least, to the editors of this volume, Alessandro Salice and Hans Bernhard Schmid, as well as two anonymous referees for their helpful criticism.

\section{References}

Allen, Jeffner (1978). Husserl's communal spirit: a phenomenological study of the fundamental structure of society. Philosophy and Social Criticism 5(1), 68-82.

Bratman, Michael (1992). Shared Cooperative Activity. Philosophical Review 101(2), 327-341.

Bratman, Michael (1993). Shared Intention. Ethics 104(1), 97-113.

Bratman, Michael (1997). I intend that we J. In: R. Tuomela \& G. Holstrom-Hintikka (Eds.) Contemporary Action Theory, Vol. 2.: Social Action (pp. 49-63). Dordrecht: Kluwer.

Caminada, Emanuele (2010). Higher-order Persons: An Ontological Challenge? Phenomenology and Mind 1, 189-196.

Caminada, Emanuele (2011). Husserls intentionale Soziologie. In: V. Mayer, C. Erhard \& M. Scherini (Eds.) (2011). Die Aktualität Husserls (pp. 56-85). Freiburg/München: Alber.

Carr, David (1973). The "Fifth Meditation" and Husserl's Cartesianism. Philosophy and Phenomenological Research 34(1), 14-35.

Carr, David (1986). Cogitamus Ergo Sumus: The Intentionality of the First-Person Plural. The Monist 69(4), 521-533.

Chelstrom, Erik (2013). Social Phenomenology: Husserl, Intersubjectivity, and Collective Intentionality. Lanham et al.: Lexington.

De Vecchi, Francesca (2011). Collective Intentionality vs. Intersubjective and Social Intentionality. An Account of Collective as Shared Intentionality. Phenomenology and Mind 1, 93- 113.

De Vecchi, Francesca (2014). Three Types of Heterotropic Intentionality. A Taxonomy in Social Ontology. In: A. Konzelmann Ziv \& H. B. Schmid (Eds.) (2014). Institutions, Emotions, and Group Agents. Contributions to Social Ontology (pp. 117-137). Dordrecht: Springer.

Durkheim, Ėmile (1893/1922). La Division du Travail. Paris: Presses Universitaire de France. 
Eilan, Naomi, Hoerl, Christoph \& Roessler, Johannes (Eds.) (2005). Joint Attention: Communication and Other Minds. Oxford: Oxford UP.

Gilbert, Margaret (1989). On Social Facts. Princeton: Princeton UP.

Gilbert, Margaret (1997). What Is It for Us to Intend? In: R. Tuomela \& G. Holstrom-Hintikka (Eds.) Contemporary Action Theory, Vol. 2.: Social Action (pp. 65-85). Dordrecht: Kluwer.

Gilbert, Margaret (2003). The structure of the social atom: Joint commitment as the foundation of human social behavior. In: F. Schmitt (Ed.), Socializing metaphysics (pp. 39-64). Lanham: Rowman \& Littlefield.

Gilbert, Margaret (2006). A Theory of Political Obligation. Membership, Commitment and the Bonds of Society. Oxford: Oxford UP.

Gilbert, Margaret (2009). Shared intention and personal intention. Philosophical Studies 144(1), 167187.

Hart, James G. (1992). The Person and the Common Life. Studies in a Husserlian Social Ethics. Dordrecht et al.: Kluwer

Helm, Bennett (2008). Plural Agents. Nô̂s 42(1), 17-49.

Husserl, Edmund (1913) [=Hua III/1]. Ideen zu einer reinen Phänomenologie und phänomenologischen Philosophie, Erstes Buch: Allgemeine Einführung in die reine Phänomenologie. Ed. by Karl Schuhmann. Den Haag: Nijhoff 1971.

Husserl, Edmund (1923). Wert des Lebens. Wert der Welt. Sittlichkeit (Tugend) und Glückseligkeit $<$ Februar 1923>. Husserl Studies 13(3), 201-235.

Husserl, Edmund (1950a) [=Hua I]. Cartesianische Meditationen. Eine Einleitung in die Phänomenologie. Ed. by Stephan Strasser Den Haag: Nijhoff.

Husserl, Edmund (1952a) [=Hua IV]. Ideen zu einer reinen Phänomenologie und phänomenologischen Philosophie. Zweites Buch: Phänomenologische Untersuchungen zur Konstitution. Ed. by Mary Biemel. Den Haag: Nijhoff.

Husserl, Edmund (1954) [=Hua VI]. Die Krisis der europä̈schen Wissenschaften und die transzendentale Phänomenologie. Eine Einleitung in die phänomenologische Philosophie. Ed. by Walter Biemel. Den Haag: Nijhoff.

Husserl, Edmund (1959) [=Hua VIII]. Erste Philosophie (1923/24). Zweiter Teil: Theorie der phänomenologischen Reduktion. Ed. by Rudolf Boehm. Den Haag: Nijhoff.

Husserl, Edmund (1966a) [=Hua X]. Zur Phänomenologie des inneren Zeitbewnßtseins (1893-1917). Ed. by Rudolf Boehm. Den Haag: Nijhoff.

Husserl, Edmund (1973a) [=Hua XIII]. Zur Phänomenologie der Intersubjektivität. Texte aus dem Nachlaß. Erster Teil: 1905-1920. Ed. by Iso Kern. Den Haag: Nijhoff.

Husserl, Edmund (1973b) [=Hua XIV]: Zur Phänomenologie der Intersubjektivität. Texte aus dem Nachlaß. Zweiter Teil: 1921-1928. Ed. by Iso Kern. Den Haag: Nijhoff.

Husserl, Edmund (1973c) [=Hua XV]. Zur Phänomenologie der Intersubjektivität. Texte aus dem Nachlaß. Dritter Teil: 1928-1935. Ed. by Iso Kern. Den Haag: Nijhoff.

Husserl, Edmund (1980) [=Hua XXIII]. Phantasie, Bildbewnßstsein, Erinnerung. Zur Phänomenologie der anschaulichen Vergegenwärtigung. Texte aus dem Nachlaß (1898-1925). Ed. by Eduard Marbach. Den Haag, Nijhoff.

Husserl, Edmund (1989) [=Hua XXVII]. Aufsätze und Vorträge (1922-1937). Ed. by Thomas Nenon \& Hans Rainer Sepp. Dordrecht: Kluwer.

Husserl, Edmund (2006) [=Hua Mat VIII]. Späte Texte über Zeitkonstitution (1929-1934). Die CManuskripte. Ed. by Dieter Lohmar. Heidelberg et al.: Springer.

Husserl, Edmund (2008) [=Hua XXXIX]. Die Lebenswelt: Auslegungen der vorgegebenen Welt und ibrer Konstitution. Texte aus dem Nachlass (1916-1937). Ed. by Rochus Sowa. Dordrecht: Springer.

Husserl, Edmund (2013) [=Hua XLII]: Grenzprobleme der Phänomenologie. Analysen des Unbewusstseins und der Instinkte. Metaphysik. Späte Ethik. Texte Aus dem Nachlass (19081937). Ed. By Rochus Sowa \& Thomas Vongehr. Dordrecht: Springer.

Johansson, Ingvar (2003). Searle's Monadological Construction of Social Reality. American Journal of Economics and Sociology 62(1), 233-255. 
Kaufmann, Felix (1930). Soziale Kollektiva. Zeitschrift für Nationalökonomie 1, 294-308.

Kaufmann, Felix (1944). Methodology of the Social Sciences. Oxford: Oxford UP.

Mathiesen, Kay (2005). Collective Consciousness. In: D. W. Smith \& A. L. Thomasson (Eds.): Phenomenology and Philosophy of Mind (pp. 235-250). Oxford: Oxford UP.

Meijers, Anthonie W. (2003). Can Collective Intentionality Be Individualized? American Journal of Economics and Sociology 62(1), 167-183.

Miettinen, Timo (2014). Transcendental Social Ontology. In: S. Heinämaa, M. Hartimo \& T. Miettinen (Eds.): Phenomenology and the Transcendental (pp. 147-171). London: Routledge.

Moran, Dermot (2011). Edmund Husserl's Phenomenology of Habituality and Habitus. Journal of the British Society for Phenomenology 42 (1), 53-77.

Mulligan, Kevin (2001). Phenomenology: Philosophical Aspects. International Encyclopedia of the Social and Behavioral Sciences (pp. 11363-11369). Oxford: Pergamon.

Neisser, Hans P. (1959). The Phenomenological Approach in Social Science. Philosophy and Phenomenological Research 20(2), 198-212.

Perreau, Laurent (2013). Le monde social selon Husserl. Dordrecht: Springer.

Pettit, Philip (1993). The Common Mind. An Essay on Psychology, Society and Politics. Oxford: Oxford UP.

Pettit, Philip (2003a). Groups with minds of their own. In: F. Schmitt (Ed.) Socializing Metaphysics. (pp. 167-193). New York: Rowman \& Littlefield.

Pettit, Philip (2003b). Akrasia, Collective and Individual. In: S. Stroud \& C. Tappolet (Eds.) Weakness of Will and Practical Irrationality (pp. 68-96). Oxford: Oxford UP.

Pettit, Philip \& Schweikard, David (2006). Joint Actions and Group Agents. Philosophy of Social Sciences 36(1), 18-39.

Pettit, Philip, List, Christian. (2011). Group Agency. The Possibility, Design, and Status of Corporate Agents. Oxford: Oxford UP.

Rovane, Carol (1998). The Bounds of Agency. An Essay in Revisionary Metaphysics. Princeton: Princeton UP.

Roth, Abraham S. (2011). Shared Agency. The Stanford Encyclopedia of Philosophy. http://plato.stanford.edu/entries/shared-agency/ [11. 02. 2014].

Salice, Alessandro (2013). Social Ontology as Embedded in the Tradition of Realist Phenomenology. In: M. Schmitz, B. Kobow \& H. B. Schmid (Eds.) The Background of Social Reality (pp. 217-231). Dordrecht: Springer.

Schmid, Hans Bernhard (2000). Subjekt, System, Diskurs: Edmund Husserls Begriff transzendentaler Subjektivität in sozialtheoretischen Beqügen. Dordrecht: Kluwer.

Schmid, Hans Bernhard (2005). Wir-Intentionalität. Kritike des ontologischen Individualismus und Rekonstruktion der Gemeinschaft. Freiburg/München: Alber.

Schmid, Hans Bernhard (2009). Plural Action. Essays in Philosophy and Social Science. Dordrecht: Springer.

Schmid, Hans Bernhard (2014). Plural Self-Awareness. Phenomenology and the Cognitive Sciences 13(1), $7-24$.

Schmid, Hans Bernhard \& Schweikard, David (2013). Collective Intentionality. Stanford Encyclopedia of Philosophy. http://plato.stanford.edu/entries/collective-intentionality/ [13. 07. 2013].

Schuhmann, Karl (1988). Husserls Staatsphilosophie. Freiburg/München: Alber.

Schütz, Alfred (1932). Der sinnhafte Aufbau der sozialen Welt. Eine Einleitung in die verstehende Soziologie. Wien: Springer.

Schütz, Alfred (1957). Das Problem der transzendentalen Intersubjektivität bei Husserl. Philosophische Rundschau 5, 81-107.

Searle, John R. (1990). Collective Intentions and Actions. In: P. Cohen, J. Morgan \& M. E. Pollack (Eds.). Intentions in Communication (pp. 401-415). Cambridge, Mass.: MIT Press.

Searle, John R. (1995). The Construction of Social Reality. London: Penguin.

Searle, John R. (2010). Making the Social World. The Structure of Human Civilization. Oxford: Oxford UP. 
Stein, Edith (1917). Zum Problem der Einfüblung. Edith Stein Gesamtausgabe, Vol. 5. Wien/Basel/Köln: Herder 2008.

Stein, Edith (1920). Beiträge zur philosophischen Begründung der Psychologie und der Geisteswissenschaften. Edith Stein Gesamtausgabe, Vol. 6. Wien/Basel/Köln: Herder 2010.

Strasser, Stephan (1975). Grundgedanken der Sozialontologie Edmund Husserls. Zeitschrift für Philosophische Forschung 1, 3-33.

Szanto, Thomas (2012). Bewusstsein, Intentionalität und mentale Repräsentation. Husserl und die analytische Philosophie des Geistes. Berlin/Boston: de Gruyter.

Szanto, Thomas (2014a). How to Share a Mind: Reconsidering the Group Mind Thesis. Phenomenology and the Cognitive Sciences 13(1), 99-120.

Szanto, Thomas (2014b). Review of Eric Chelstrom (2013): Social Phenomenology: Husserl, Intersubjectivity, and Collective Intentionality. International Journal of Philosophical Studies 21(2), 296-301.

Szanto, Thomas (forthcoming a). Collectivizing Persons and Personifying Collectives: Reassessing Scheler's Concept of Gesamtperson. In: T. Szanto, D. Moran (Eds.). The Phenomenology of Sociality: Discovering the ' $W e$ '. London/New York: Routledge.

Szanto, Thomas (forthcoming b). Stein on Shared Experiences and Collective Empathy. In: Human Studies.

Theunissen, Michael (1965/1977). Der Andere. Studien zur Sozialontologie der Gegenwart. Berlin/New York: de Gruyter.

Thomasson, Amie (1997). The Ontology of the Social World in Searle, Husserl and Beyond. In: Phenomenological Inquiry 21, 109-136.

Tollefsen, Deborah P. (2002). Collective Intentionality and the Social Sciences. Philosophy of the Social Sciences 32(1), 25-50.

Tollefsen, Deborah P. (2004). Collective Intentionality. The Internet Encyclopedia of Philosophy. http://www.iep.utm.edu/coll-int/ [04. 08. 2004].

Tönnies, Ferdinand (1935). Gemeinschaft und Gesellschaft. Grundbegriffe der reinen Soziologie. 8th Edition. Darmstadt: Wissenschaftliche Buchgesellschaft 1991.

Toulemont, René (1962). L'Essence de la société selon Husserl. Paris: Presses Universitaires de France.

Tuomela, Raimo (1995). The Importance of Us. A Philosophical Study of Basic Social Notions. Stanford: Stanford UP.

Tuomela, Raimo (2007). The Philosophy of Sociality. The Shared Point of View. Oxford: Oxford UP.

Tuomela, Raimo (2013). Who is Afraid of Group Agents and Group Minds? In: M. Schmitz, B. Kobow \& H.B. Schmid (Eds.) The Background of Social Reality Selected Contributions from the Inaugural Meeting of ENSO (pp. 13-36). Dordrecht: Springer.

Tuomela, Raimo \& Miller, Kaarlo (1988). We-intentions. Philosophical Studies 53(3), 367-389.

Uygur, Nermi (1959). Die Phänomenologie Husserls und die "Gemeinschaft." Kant-Studien 50 (14), 439-460.

Velleman, David (1997). How to Share an Intention. Philosophy and Phenomenological Research, 57(1), $29-51$.

Vierkandt, Alfred (1928). Gesellschaftslehre. 2nd Edition. Stuttgart: Ferdinand Enke.

Weber, Max (1922). Wirtschaft und Gesellschaft. Grundriß der verstehenden Soziologie. Tübingen: Mohr Siebeck 2002.

Zahavi, Dan (2001). Husserl and Transcendental Intersubjectivity. A Response to the Linguistic-Pragmatic Critique. Transl. by E. A. Behnke. Athens, OH: Ohio UP.

Zahavi, Dan (2010). Empathy, Embodiment and Interpersonal Understanding: From Lipps to Schutz. Inquiry 53(3), 285-306.

Zahavi, Dan (forthcoming). Self and Other: Exploring Subjectivity, Empathy, and Shame. Oxford: Oxford UP. 